\title{
The Relationship between Entrepreneurial Orientation and Performance; Evidence from Turkish SMEs
}

\author{
Nida Platin ${ }^{1}$, Hande Sinem Ergun ${ }^{1}$ \\ ${ }^{1}$ Faculty of Business Administration, Marmara University, Istanbul, Turkey \\ Correspondence: Hande Sinem Ergun, Professor, Faculty of Business Administration, Marmara University, Istanbul, \\ Turkey.
}

Received: May 8, 2017

Accepted: May 26, 2017

Online Published: May 31, 2017

doi:10.11114/bms.v3i2.2408

URL: https://doi.org/10.11114/bms.v3i2.2408

\begin{abstract}
This research aims to find the factors linked to Entrepreneurial orientation and corporate entrepreneurship that effect export and sales growth performance of SMEs. Thereby a model was developed to reveal the relationship between these factors. The questionnaire had parts such as general information about firm and owner/manager, entrepreneurial orientation, corporate entrepreneurship and growth in sales revenue and exportation rate over the most recent 3 year period of the SMEs. The measurements have been gathered together in 72 item in survey and applied to 163 SMEs manufacturing generally in Ankara and Bursa, Turkey. The result showed that entrepreneurial orientation is positively and significantly related with SMEs' sales growth and exportation performances. SMEs have to be proactive in any circumstances and especially exporter SMEs need to be more risk taking than proactive and least innovative. Also organizational boundaries has greater effect on performance than other dimensions of corporate entrepreneurship.
\end{abstract}

Keywords: entrepreneurial orientation, corporate entrepreneurship, performance, sales growth, exportation, SMEs

\section{Introduction}

Cantillon, one of the first researcher that used formally the term "entrepreneurship" in his study published in 1755 , the main factor that separates entrepreneurs from employed workers was the uncertainty and risk taken by the former. The individual who presents entrepreneurial behavior takes risks and behaves proactively and performs product-market innovations (Miller, 1983). Entrepreneurial behavior is generally related with Schumpeterian notion of an entrepreneur who has two key elements linked to entrepreneurial behavior. The first is the ability to recognize an opportunity or ability to create an opportunity. The second is the exploitation or commercialization of the opportunity (Audretsch, 2012). Entrepreneurs either create an organization or work through an organization (intrapreneurs) they must develop the new opportunities and values they envision which involves not only risks but also obstacles and barriers that may stand in the way of the entrepreneur's efforts (Brenkert, 2009).

The beginning of organization is flexible, adaptive and by this way achieving competitive advantage against large bureaucratic organizations. But as business starts growing, organizations also grow and change in this way managerial processes and structures are beginning to get complex because of its larger amount (Duobienè, 2008). Organizations deal with the internal challenges of modernizing bureaucratic structures and processes that cause to slow decision making and an inability to adapt easily to new situations (Hammer\&Champy, 1994).Companies generally reduce costs, the numbers of employees or move production sites to low-cost areas in order to respond to their obstacles and challenges however these steps produce short-term effects and do not provide the long-term effects that the companies need (Schmelter et al, 2010). Businesses have to continually re-examine their market orientation strategies and adapt flexibly in order to secure global competitiveness, growth and survival (Van Wyk\& Adonisi, 2012).

In this context entrepreneurial orientation reflects how a firm operates rather than what it does and means firm's strategic orientation to capture specific entrepreneurial aspects of decision-making styles, methods, and practices (Wiklund\&Shepherd, 2005). Firms with high levels of entrepreneurial orientation are in tendency to constantly scan and observe their operating environment in order to find new opportunities and reinforce their competitive positions. Firms scan and monitor their environment to look for information that can help them better meet the needs of their customers, manage their risk taking, as well as challenge their competitors (Keh et al, 2007).

Many SMEs, refer to the Small and Medium Sized Enterprises, are started up by entrepreneurially-minded people who 
use the opportunities that existing or larger firms have not realized or are not interested in. Thusly the owner-managers of small businesses acted entrepreneurially in the first place and created the business, that is, he or she recognized an opportunity and obtained the resources necessary to turn it into a business (Hulbert et al, 2013). During economic downturns, the role of SMEs and entrepreneurship is stronger therefore, SMEs are confront strong expectations for their role to be key players when economies will be recovering from the present global decline (Soininen et al, 2012).

SMEs generally have the biggest shares in their countries' economies as well as they have vital places for the developed countries and developing countries and in each development plan, the most important roles and responsibilities have been provided to the SMEs (Kaya \& Alpkan, 2012). SMEs' are a major part of the Turkish economy owing to their large share in the total number of enterprises and in total employment. Their average profile is different from that of SMEs in the European Union or in most other OECD countries in that their average workforce and turnover are much smaller (OECD,2004). In 2013 Turkish Small and Medium Sized Enterprises (SMEs) accounted for 99.8\% of total enterprises, $74.2 \%$ of employment and $63.8 \%$ of total turnover. SMEs in Turkey realized $56.4 \%$ of exports during 2014 (TUIK,2015). The entry of large numbers of young people into the labour market, enormous change of jobs from the farm sector to industry and services, and the increasing ranks of women in the labour market will require substantial new job creation in industry and services over the years ahead (OECD,2004).

Strong growth in a climate of stability is thus an essential prerequisite for the development of SMEs, which in many cases are not as well equipped as larger firms to protect themselves from internal and external shocks.. This research aims to find the factors linked to Entrepreneurial orientation and corporate entrepreneurship that effect export and sales growth performance of SMEs. Thereby a model was developed to reveal the relationship between these factors. The questionnaire had parts such as general information about firm and owner/manager, entrepreneurial orientation, corporate entrepreneurship and growth in sales revenue and exportation rate over the most recent 3 year period of the SMEs. The measurements have been gathered together in 72 item in survey and applied to 163 SMEs manufacturing generally in Ankara and Bursa, Turkey.

Therefore the main objective of this study is to propose model that will help SMEs to be entrepreneurial to obtain stronger growth against the rivals in order to be a guide for progress of SMEs in further studies. We hope to develop a complex and multidimensional model for finding the factors that affect the entrepreneurship within small firms. Our aims in this study are (a) examine independently the relationship between of entrepreneurial orientation and corporate entrepreneurship on performance (sales growth and exportation); (b) analyze the impact of EO and CE together on performance (sales growth and exportation). In order to reach these objectives, firstly a literature review about EO and $\mathrm{CE}$, their dimensions, their relationship with the organizational performance will be explained. After literature review, the research model and hypothesis developed based on this literature review will be provided in research methodology. Thirdly, the results of empirical study will be explained. Conclusion and the limitations of the study will be presented as the final phase.

\section{Literature Review}

Change which is the essential element of entrepreneurial processes, takes place when habitual practices are switched with the new ones after practical experience has come up when the current ones no longer serve the organization (Peltola, 2013). Entrepreneurial behavior can appear in any type of organizational ranging from small business to large corporation, from new startup to established company, from non-profit organization to government agency. The characteristics of the individuals are essential within organizations that exhibit entrepreneurial postures (Audretsch, 2012). Entrepreneurial organization and usual small business venture organizations differ in three characteristics: innovations, strategic objectives and potential for growth. Furthermore, entrepreneurial organizations usually go beyond small business venture because of formally articulated strategic objectives, including growth target, market development, market share or market position (Duobiene,2017). The entrepreneurial spirit involves the ability to develop new idea sinto concept and the capability to use the same resource differently to produce heterogeneous outputs (Bucktowar et al, 2015).

Entrepreneurial orientation literature was developed by Covin and Slevin (1989), based on the earlier work of Khandwalla (1977) and Miller and Friesen (1982) which consist of the three dimensions of entrepreneurial orientation innovation, proactiveness, and risktaking (Alarape, 2014). Miller and Friesen (1982) assume that EO obtains "the nature of the innovative strategy of the firm, something that is often determined by executives with regard to their goals and temperaments"(Miller\&Friesen ,1982). While Mintzberg (1973) qualifies the entrepreneurial manner as a strategymaking is managed by the active search for new opportunities", Covin and Slevin (1989) identify EO as the "processes, practices and decision-making activities that direct to new entry" (Lumpkin\&Dess, 1996) .Generally doctorinaires do not evaluate a firm entrepreneurial if they change their technology or product line simply by imitating competitors while refusing to take any risks (Covin\&Wales, 2011). 
Entrepreneurial orientation is explained by Miller in 1983 with the combination of three dimensions innovativeness, proactiveness, and risk taking. Firms with a strong innovative culture, a proactive point of view against the competitors and a willingness to take risks are more likely involved in entrepreneurial operations (Zhang et al, 2012). Innovativeness refers to firm's tendency to engage in new ideas, experimentation, creative processes that may conduce new products, new technology and services (Alarape, 2014).Proactiveness is an opportunity seeking, forward looking perspective involving the anticipation and acting on future needs which may or may not related to the present line of operation and the aggressiveness in responding to trends and demand that already exist in the marketplace (Lumpkin\&Dess, 2001). Risk-taking, is the core concept of entrepreneurship. Entrepreneur is defined as someone who specializes in responsibility, legal decisions on the location, type and use of goods and affects resources and institutions (Parsian\&Mobaraki,2016).

Entrepreneurial firm "engages in product market innovation, undertakes somewhat risky ventures, and is the first to come up with "proactive" innovations, beating competitors to the punch" (Miller, 1983). Lumpkin and Dess (1996) have been included two complemental dimensions; competitive aggressiveness and autonomy. The competitive aggressiveness is closely linked with the last words of Miller's citation ("beating competitors to the punch") (Fayolle et al,2008). Aggressiveness is a serious challenge directly with competitors to enter the market or improve the situation in order to surpass competitors in the market or industry (Parsian\&Mobaraki,2016). The fifth dimension of entrepreneurial orientation (EO) "autonomy" is borrowed from Burgelman (1983) reflecting strategic initiative of individuals at the operational levels in the organization (Fayolle et al,2008). Autonomy refers to an independent action of an individual or team to forward an idea to accomplish its mission, regardless of organizational boundaries (Parsian\&Mobaraki,2016).

Mintzberg (1973) characterized EO as strategic decision-making in consequence of active search for new opportunities in uncertain environments in order to realize dramatic growth (Covin and Wales, 2011). As entrepreneurship is new entry and EO signifies the process, practices, and decision-making activities that lead to new entry with new or existing goods and services to new or established markets (Lumpkin\&Dess,1996). Entrepreneurial orientation is a process that firms notice opportunities and act to creatively organize transactions between factors of production to create surplus value (Jones \&Butler, 1992).Eventually as a firm level behavior, EO refers to the business orientation of an enterprise, management practices as well as the owner-manager behavior and a mindset that anticipates new products and market needs (Bucktowar et al, 2015).

The conception of corporate entrepreneurship derived from Schumpeter's $(1934,1942)$ approach identify the creation process of new value at organizational level based on a unique combination of resources and opportunities to be used. Corporate entrepreneurship is entrepreneurship at organizational level (Duobiene, 2013).Corporate new venture creation was named "intrapreneuring" by Gifford Pinchot (1985) due to it means building entrepreneurial businesses within the scope of existing firms (Dess\&Lumpkin, 2005). An "intrapreneur" act as an entrepreneur within the company and encourages employees and middle managers to work against the existing rules of the organization to produce change and innovation (Zahra et al,2013). CE relates to firm innovation, market entry and creation and strategic renewal activities. CE requires using innovation,operations, and supply chains to secure agility and responsiveness to changing markets; accessing the technology of other entities; and/or venturing into new product and geographic markets (Holmes et al,2016). Corporate entrepreneurship is a process that goes on inside an existing firm and leads new business ventures, other innovative activities and orientations such as development of new products, services, technologies, administrative techniques, strategies (Antoncic \&Hisrich, 2001). CE is a strategic orientation including the renewal of products, processes, services, strategies or moreover whole organizations (Covin\& Miles, 1999). For example Textbook publishers could distribute digital PDFs directly to students and lowering the price of the text to the student could result in significant savings (Morrish et al, 2011).

Guth and Ginsberg (1990) indicated that CE cause two major types of phenomena: new venture creation within existing organizations and the transformation of ongoing organizations in terms of strategic renewal, namely, corporate venturing and strategic entrepreneurship. Corporate venturing is adding of new businesses to the corporation. By contrast, strategic entrepreneurship is the exhibition of large-scale or highly consequential innovations for the firm's pursuit of competitive advantage. With strategic entrepreneurship, innovation can be in any of five areas - the firm's strategy, product offerings, served markets, internal organization (i.e., structure, processes, and capabilities), or business model (Hornsby et al, 2013). While innovation is considered as a process in which inventions are more marketable or value creating products, processes, services, or organizational changes; venturing includes the creation of a business through either a new business unit, getting a new business, or through partnering with another organization (Hayton, 2005). Promoting CE requires more clarified approach to management including decentralization of authority, participation in decision making, cooperation, avoidance of bureaucracy and encouragement of risk taking and creativity (Hayton, 2005).

Organisational self-renewal is always related with changes in the strategy. New business venturing, entering new 
markets (creation of new product market arena) and corporate venturing are related to CE (Duobiene,2017). Entrepreneurial behavior is at the core of $\mathrm{CE}$ strategies refers to the recognition and exploitation of entrepreneurial opportunities across the entire organization (Peltola, 2013). Firms that want to engage in successful corporate entrepreneurship need to have an entrepreneurial orientation (EO) which refers to the strategy-making practices that businesses use to identify and launch corporate ventures (Dess \&Lumpkin, 2005). Miller (1983) defines an entrepreneurial firm: "an entrepreneurial firm is one that engages in product-market innovation, undertakes somewhat risky ventures, and is first to come up with 'proactive' innovations, beating competitors to the punch" (Miller,1983). The entrepreneurial managers provide reforms and frameworks to firms for inclusive changes and innovation in the existing structure. Developing the new sources reflects the struggle to extend an organization's competitive advantage. Innovations are usually produced within the organization that significantly regulates the stability of competition (Serai,2017).

Managing firm resources properly is significant to implement strategies that provide firms competitive advantage.Daft (1983) the firm resources as all assets, capabilities,organizational processes, firm attribute, information,knowledge that are controlled by a firm. Furthermore, tangible or intangible resources are also the strengths and weaknesses of a firm which are criticital to implement strategies (Bucktowar et al, 2015). Consequently entrepreneurial orientation represents a frame of mind that reflects a firm's ongoing process and corporate culture (Dess\&Lumpkin, 2005). EO is defined as a firm's tendency to encourage and follow entrepreneurial opportunities, whether discovered or created. The widespread use of the Covin and Slevin studies $(1986,1989)$, coupled with researchers' emphasis on EO, might have led some to believe that the two research streams (CE and EO) were one and the same (Zahra et al,2013). However corporate entrepreneurship is formal or non-formal activities purposed to create new ventures within established firms through innovations of products or processes and development of markets (Zahra ,1991).

As entrepreneurship is the act of developing a new venture outside an existing organization, corporate entrepreneurship by contrast is the practice of developing new venture within the existing organization to take the advantage of a new opportunity and create economic value (Parker, 2011). Accordingly Sharma and Chrisman (1999) corporate entrepreneurship comprise the re-development of new businesses within the mother company, the transformation of key areas in a business and the renewal of an existing business (Sharma\&Chrisman,1999). However, the corporate entrepreneurship concept provoke not only entrepreneurial processes within an existing organization as it is related with external environment through of the organization it provide opportunities for proactive strategic behavior through environmental scanning (Duobiene,2013).

\section{Research Hypotheses}

Change which is the essential element of entrepreneurial processes, takes place when habitual practices are switched with the new ones after practical experience has come up when the current ones no longer serve the organization (Peltola, 2013). Entrepreneurial behavior can appear in any type of organizational ranging from small business to large corporation, from new startup to established company, from non-profit organization to government agency (Audretsch, 2012). Entrepreneurial organizations often take the initiative actions to which competitors then respond, by this way they are frequently first-to-market with new product offerings (Anderson\&Eshima, 2013). Entrepreneurship is an opportunity oriented process that provide people to realize the high potential venture regardless of the resources and the applicable attempt for the proper way of thinking would be the idea of entrepreneurial management on the organizational level (Dyduch, 2008).

The framework presented here is based on sales growth and exportation performance of the firms. Performance is critically dependent on the entrepreneurial orientation and corporate entrepreneurship strategic behaviors of the firms.

\subsection{Entrepreneurial Orientation and Performance}

Innovativeness, risk taking,and proactiveness are seen as the core elements of EO that activates the entrepreneurial process from opportunity recognition/opportunity creation through to the development from the genesis of an idea to the startup of a business, from the idea for a product to its introduction or setting up an international venture (Harms, 2013). Entrepreneurial orientation specified that entrepreneurial firms incline to take more risks than other types of firms, especially when confront with conditions of uncertainty. Entrepreneurial firms consists of product- market innovation, proactiveness of decision-making, and risk-taking and so the level of entrepreneurship demonstrated by a firm accordingly the total of these three sub-dimensions. Also an "entrepreneurial" firm exhibit high levels of each dimension (Kreiser\&Davis, 2010).

Entrepreneurial firm "engages in product market innovation, undertakes somewhat risky ventures, and is the first to come up with "proactive" innovations, beating competitors to the punch" (as cited in Miller, 1983,p.771). Lumpkin and Dess (1996) have been included two complemental dimensions; competitive aggressiveness and autonomy. The competitive aggressiveness is closely linked with the last words of Miller's citation ("beating competitors to the punch"). 
The fifth dimension of entrepreneurial orientation (EO) "autonomy" is borrowed from Burgelman (1983) reflecting strategic initiative of individuals at the operational levels in the organization (Fayolle et al ,2008).

Each dimension of entrepreneurial orientation has unlimited positive effect on performance. Innovative companies that have seen as the engines of economic growth, create extraordinary economic performance by inventing and pioneering new products and technologies. Proactive companies can originate first-mover advantage, target premium market segments, charge high prices, and ,skim the market ahead of competitors. They can dominate the distribution channels and create brand recognition and thusly control the market. The relation between risk taking and performance is less obvious. Because while tried-and-true strategies may cause to high performance, risky strategies generate performance variation, some projects fail while others succeed, may be more profitable in the long term (Wiklund\&Shepherd, 2005). Miller (1983) Lumpkin and Dess (1996) suggest that entrepreneurial activities influence a company's performance by increasing its commitment to innovation by offering innovative products or processes. These companies have created innovative products to target new market segments and enter new foreign markets, a process that has renewed their operations, improved their profitability and achieve superior financial performance (Zahra \&Garvis, 2000).

\subsection{Corporate Entrepreneurship and Performance}

Successful entrepreneurial organization includes management support for corporate entrepreneurship, work discretion, rewards/ reinforcement, time availability, and organizational boundaries (Hornsby et al,2002). Top management support promote entrepreneurial behavior by championing innovative ideas and providing the resources for people in order to take entrepreneurial actions. Work discretion tolerates failure, provides decision-making independence and transfer the authority and responsibility to lower-level managers and workers. Rewards and reinforcement; the organization use a system that reward based on entrepreneurial activity and success. Reward system encourage risk taking and innovation and has strong effect on individual's tendency to behave in entrepreneurial manner. Time availability is a perception of extra time for individuals and groups to pursue innovation to support goals of the organization. Organizational boundaries define acceptable behaviors, job-related expectations, standarts, process and procedure to be followed and so individuals may take initiative under such circumstances. Flexible organizational boundaries is beneficial to encourage entrepreneurial activity due to they advance the flow of information between the external environment and organization and also between departments and divisions of the organization (Kuratko et al, 2014). The organizational reward systems are acceptable as a part of management support and to perceptions of innovation supportiveness due to reward system can have a significant effect on innovative activity as the part of fostering entrepreneurship (Lerner et al, 2009).

$\mathrm{CE}$ activities can enrich a company's performance by creating new knowledge that establish new competencies or regenerating existing ones. CE activities use this knowledge to develop new competencies or improve existing ones and so that enlarge the company's competencies in evaluating its markets or creating and commercializing new knowledge-intensive products, processes, or services (Zahra et al, 1999). Corporate entrepreneurship is a strategic orientation containing the rejuvenating of products, processes, services, strategies or even the entire organizations and so $\mathrm{CE}$ promotes continuous competitive advantage through the sustained generation and exploitation of new sources of knowledge. Therefore, corporate entrepreneurship has an important effect on organizational financial and market performance (Ozdemirci ,2011). Zahra (1991) suggest that CE is definitely associated with company's financial performance, and the strength of this relationship tends to grow over time, even after controlling for past performance. Importantly, CE-performance relationship can significantly reinforce over time and so CE should not be seen as a short-term "fix," but as a long-term strategy for succeed higher level financial performance (Zahra and Covin, 1995).

Based on the above analysis, each entry mode has wide scope for application. The entrepreneurial orientation strategies on firms' performance are hypothesized as follows:

H0: Entrepreneurial orientation affects sales growth of performance.

H1: Corporate Entrepreneurship affects sales growth of performance.

H2: Corporate Entrepreneurship affects exportation of performance

H3: $E O$ and $C E$ affects sales growth of performance

H4: EO and CE affects exportation of performance

\section{Research Methodology}

\subsection{Data Collection}

The target for this study consists of randomly selected small and medium sized businesses operates in several cities over Turkey. A brief introduction explaining the purpose of the study was given by the researcher to the participants. Also, the assurance of the confidentiality of the study was provided by mentioning the academic purposes of the study. The questionnaires were personally distributed or e-mailed to the 187 respondents. Over a span of six weeks, a total of 163 
questionnaires are completed in full, yielding a \%87 response rate.The participants were asked to evaluate corporate entrepreneurship on 48 items, entrepreneurial orientation perception on 15 items and finally performance progress on 2 items. Also 15 demographic questions exist in the questionnaire. questionnaire. The fulfillment of the questionnaires about 20 minutes. Respondents were asked to complete questionnaires based on six-point Likert-type measurement scale, ranging from ( $1=$ strongly disagree $)$ to $(6=$ strongly agree $)$.

\subsection{Participants}

In total the questionnaire was applied to 187 manufacturing SMEs operating in generally in Ankara and Bursa. We could used the 163 questionnaire in two distinct industries, a growing and a shrinking industry, are selected. In an convenient sample of 163 SMEs, the owner managers 80,4 \%are males and 19,6 \% are females. Examination of ages indicates that $49,1 \%$ of participants are between $25-35$ years of age and $30,7 \%$ are between $36-45$ years old. Majority of the participants are high school graduated $30,1 \%$ and university graduated $33.7 \% .29,4 \%$ of participant SMEs are furniture sector and 10,4 \% are in steel industry. $38,0 \%$ of SMEs operates 21 years and over.

\subsection{Entrepreneurial Orientation}

Entrepreneurial orientation (EO) of firms are used as independent varibles. Entrepreneurial orientation was measured using the 9 item scale proposed by Covin and Slevin (1989), which contains some items adapted from Khandwalla (1976/1977) and Miller and Friesen (1982). These nine items include three items that assess the innovation dimension of EO, three items to measure proactiveness and three to measure risk taking (Green et al, 2008). As Lumpkin and Dess (1996) integrated two new additional dimensions, competitive aggressiveness and autonomy. Lumpkin and Dess (1996, 2001) underline that proactiveness and competitive aggressiveness are differential due to proactiveness is response to opportunities while competitive aggressiveness is response to threats. Autonomy is the independent action of an individual or a team in bringing forth an idea or a vision (Casillas and Moreno, 2010). Thusly the innovativeness, risk taking, proactiveness, competitive aggressiveness and autonomy dimensions of the scale were represented by 15 items.

\subsection{Corporate Entrepreneurship}

Corporate Entrepreneurship (CE) of firms are used as mediating variables. The Corporate Entrepreneurship Assessment Instrument (CEAI) originally developed by Kuratko, Montagno, and Hornsby (1990) and further refined in more recent studies (Hornsby, Kuratko, Shepherd, and Bott, 2009; Hornsby et al., 2002). CEAI presented to evaluate firm's “organizational preparedness for CE antecedents of managers' entrepreneurial actions. These antecedents, along with an interpretation of them, are as follows: (1) top management support (the willingness of top-level managers to facilitate and promote entrepreneurial behavior, including the championing of innovative ideas and providing the resources people require to take entrepreneurial actions); (2) work discretion (top-level managers' commitment to tolerate failure, provide decision-making latitude and freedom from excessive oversight and to delegate authority and responsibility to managers); (3) rewards/reinforcement (developing and using systems that reward based on performance, highlight significant achievements, and encourage pursuit of challenging work); (4) time availability (evaluating workloads to ensure that individuals and groups have the time needed to pursue innovations and that their jobs are structured in ways that support efforts to achieve short- and long-term organizational goals); and (5) organizational boundaries (precise explanations of outcomes expected from organizational work and development of mechanisms for evaluating, selecting, and using innovations) (Hornsby et al, 2013). The CEAI scale composed of 48 descriptive statements.

\subsection{Performance}

The performance was often measured by the business volume including sales and exportation. The informants have been asked to indicate their firm's performance over the last three years in terms of total sales and in exportation.

\section{Analysis and Results}

\subsection{Reliability Analysis}

The factor analysis based on varimax rotation was conducted on 15 entrepreneurial orientation variables. Through the analysis, factor loadings less than 0,6 are selected to be extracted since 0,6 is considered as the significant factor loading.Two innovativeness and two proactiveness items loaded on the first factor (lowest loading was 0,715), two risk-taking and one proactiveness items loaded on the second factor (lowest loading was 0,723 ). Hence we named the first factor 'proactive-innovativeness' and the second factor labeled as 'proactive-risk taking'. These two factors of entrepreneurial orientation as the independent variable explain $65,308 \%$ of the total variance therefore, to great extent, widely recognized the dimensions of entrepreneurial orientation are applicable to explain Turkish firms behaviors.

Also the factor analysis based on varimax rotation was also conducted on 45 corporate entrepreneurship variables. The same with entrepreneurial orientation, factor loadings less than 0,6 are extracted. Six 'work discretion' items loaded on the first factor (lowest loading was 0,622 ), four 'management support' items loaded on the second factor (lowest 
loading was 0,696 ) and four 'organizational boundaries' items loaded on the third factor (lowest factor was 0.724 ). These remained three factors of the mediating variable explain $62,897 \%$ of the total variance.

Reliability analysis that ensures stability and consistency of the results, was assessed using Cronbach's alpha. Factors with Cronbach's alpha less than 0,7 are extracted. The results of this test are shown in Table 1 and Table 2.

Table 1. Reliability and Factor Analysis of EO scale

\begin{tabular}{|c|c|c|c|c|}
\hline & $\begin{array}{l}\text { Factor } \\
\text { Loading }\end{array}$ & $\begin{array}{l}\% \text { Variance } \\
\text { Explained }\end{array}$ & $\begin{array}{l}\text { Cronbach's } \\
\text { Alpha }\end{array}$ & $\begin{array}{l}\text { Number } \\
\text { of items }\end{array}$ \\
\hline Proactive innovativeness & & 35,701 & 0,801 & 4 \\
\hline $\begin{array}{l}\text { Very often, my firm is the first to introduce new products / services, } \\
\text { process, technologies \& administrative techniques. }\end{array}$ & 0,821 & & & \\
\hline $\begin{array}{l}\text { In dealing with competition, my firm often first to initiate actions to } \\
\text { competitors, for which the competitors then respond }\end{array}$ & 0,792 & & & \\
\hline $\begin{array}{l}\text { In general my firm favor a strong emphasis on } \\
\text { Research\&Development,technological leadership and innovations }\end{array}$ & 0,745 & & & \\
\hline $\begin{array}{l}\text { Changes in products or service line have usually been quite } \\
\text { dramatic. }\end{array}$ & 0,715 & & & \\
\hline Proactive Risk taking & & 29,607 & 0,745 & 3 \\
\hline $\begin{array}{l}\text { TMT has strong proclivity for high risk projects (with chances very } \\
\text { high returns) }\end{array}$ & 0,859 & & & \\
\hline $\begin{array}{l}\text { In general, my firm has a strong tendency to be ahead of others } \\
\text { in introducing novel ideas or products. }\end{array}$ & 0,791 & & & \\
\hline $\begin{array}{l}\text { Promotion usually follows the development of new and innovative } \\
\text { ideas }\end{array}$ & 0,723 & & & \\
\hline Total Varience Explained & & 65,308 & & \\
\hline Kaiser-Meyer-Olkin measure of sampling adequacy & 0,774 & & & \\
\hline Chi square Barlett's test of sphericity & 390,625 & & & \\
\hline Significance & 0,000 & & & \\
\hline
\end{tabular}

Table 2. Reliability and Factor Analysis of CE scale

\begin{tabular}{|c|c|c|c|c|}
\hline & $\begin{array}{l}\text { Factor } \\
\text { Loading } \\
\end{array}$ & $\begin{array}{l}\% \text { Variance } \\
\text { Explained }\end{array}$ & $\begin{array}{l}\text { Cronbach's } \\
\text { Alpha }\end{array}$ & $\begin{array}{l}\text { Number } \\
\text { of items }\end{array}$ \\
\hline Work Discretion & & 24,957 & 0,850 & 6 \\
\hline I have the freedom to decide what I do on my job. & 0,824 & & & \\
\hline $\begin{array}{l}\text { This organization provides the chance to do something that makes } \\
\text { use of my abilities. }\end{array}$ & 0,803 & & & \\
\hline $\begin{array}{l}\text { This organization provides the chance to be creative and try my } \\
\text { own methods of doing the job. }\end{array}$ & 0,748 & & & \\
\hline This organization provides freedom to use my own judgment. & 0,744 & & & \\
\hline $\begin{array}{l}\text { A worker with a good idea is often given free time to develop that } \\
\text { idea. }\end{array}$ & 0,659 & & & \\
\hline $\begin{array}{l}\text { This organization supports many small and experimental projects } \\
\text { realizing that some will undoubtedly fail. }\end{array}$ & 0,622 & & & \\
\hline Management Support & & 20,339 & 0,839 & 4 \\
\hline $\begin{array}{l}\text { Upper management is aware and very receptive to my ideas and } \\
\text { suggestions. }\end{array}$ & 0,857 & & & \\
\hline $\begin{array}{l}\text { In my organization, developing one's own ideas is encouraged for } \\
\text { the improvement of the corporation. }\end{array}$ & 0,855 & & & \\
\hline My organization is quick to use improved work methods & 0,744 & & & \\
\hline $\begin{array}{l}\text { Promotion usually follows the development of new and innovative } \\
\text { ideas }\end{array}$ & 0,696 & & & \\
\hline Organizational Boundaries & & 17,601 & 0,775 & 4 \\
\hline $\begin{array}{l}\text { My job description clearly specifies the standards of performance } \\
\text { on which my job is evaluated. }\end{array}$ & 0,822 & & & \\
\hline $\begin{array}{l}\text { I clearly know what level of work performance is expected from } \\
\text { me in terms of amount, quality, and timeliness of output. }\end{array}$ & 0,773 & & & \\
\hline $\begin{array}{l}\text { There are many written rules and procedures that exist for doing } \\
\text { my major tasks. }\end{array}$ & 0,757 & & & \\
\hline $\begin{array}{l}\text { In the past three months, my immediate supervisor discussed my } \\
\text { work performance with me frequently. }\end{array}$ & 0,724 & & & \\
\hline Total Varience Explained & & 62,897 & & \\
\hline Kaiser-Meyer-Olkin measure of sampling adequacy & 0,836 & & & \\
\hline Chi square Barlett's test of sphericity & 952,769 & & & \\
\hline Significance & 0.000 & & & \\
\hline
\end{tabular}




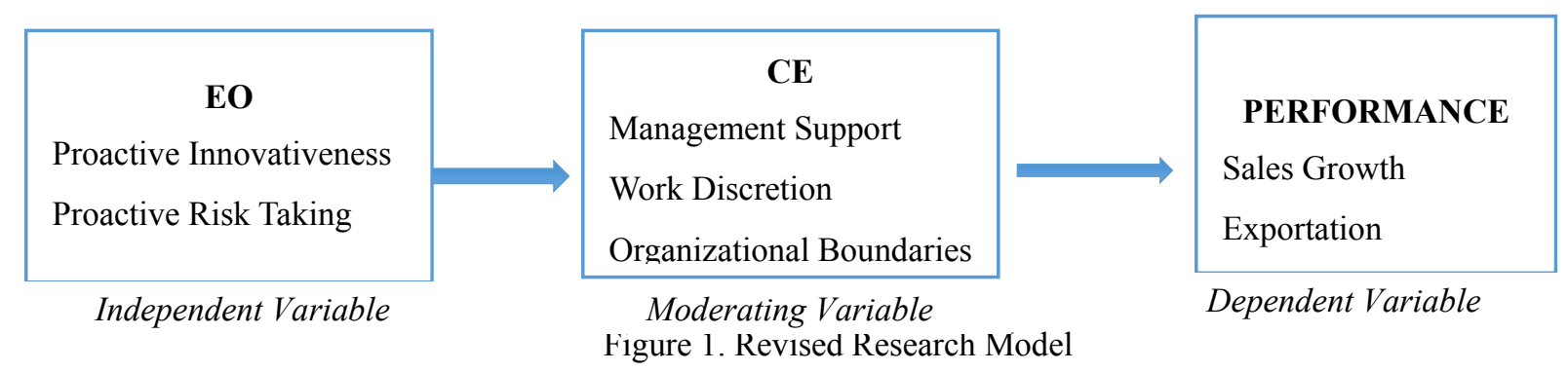

\subsection{Multiple Regression Analysis Results}

To determine the validity of hypotheses (Ho-H1-H2), we conducted a multiple regression analysis by using factors scores that are resulted in the factor analysis.First hypothesis examined that if entrepreneurial orientation affects sales growth of performance. The results revealed a positive and significant association between proactive innovativeness, proactive risk taking and sales growth. Our second hypothesis (H1) expected a positive relationship between corporate entrepreneurship and sales growth. It has been observed while work discretion $(\mathrm{p}=0,001<0,05)$ is significant, management support $(p=0,680>0,05)$ does not influence sales growth. But organizational boundaries $(p=0,024<0,05)$ is inversely correlated with sales growth as organizational boundaries decrease sales growth increase. Our another hypothesis anticipated a positive relationship between corporate entrepreneurship and exportation dimension of performance. It also show that the regression explained no impact of management support $(p=0,333>0,05)$ and work discretion $(\mathrm{p}=0,627>0,05)$ to exportation. But still Organizational boundaries $(\mathrm{p}=0,007<0,05)$ inversely related with the exportation. The relationship between entreprneurial orientation and exportation is not supported by our data untill we include corporate entrepreneurship as you may see below.

\subsection{Hierarchical Regression Analysis}

\subsubsection{Hierarchical Regression Analysis for Sales Growth}

We conducted a hierarchical regression analysis for the hypothesis (H3-H4) as the samples are represented in Table 3. R square points that organizational boundaries, proactive innovativeness and proactive risk taking explain $19,7 \%$ of the variance of sales growth of performance. While proactive innovativeness $(p=0,006<0,05)$ and proactive risk taking $(p=0,023<0,05)$ affect sales growth of performance directly, Organizational boundaries inversely $(p=0,005<0,05)$ correlated with sales growth that means as OB diminsh, the sales growth increase.

Table 3. Hierarchical Regression Results for Sales Growth

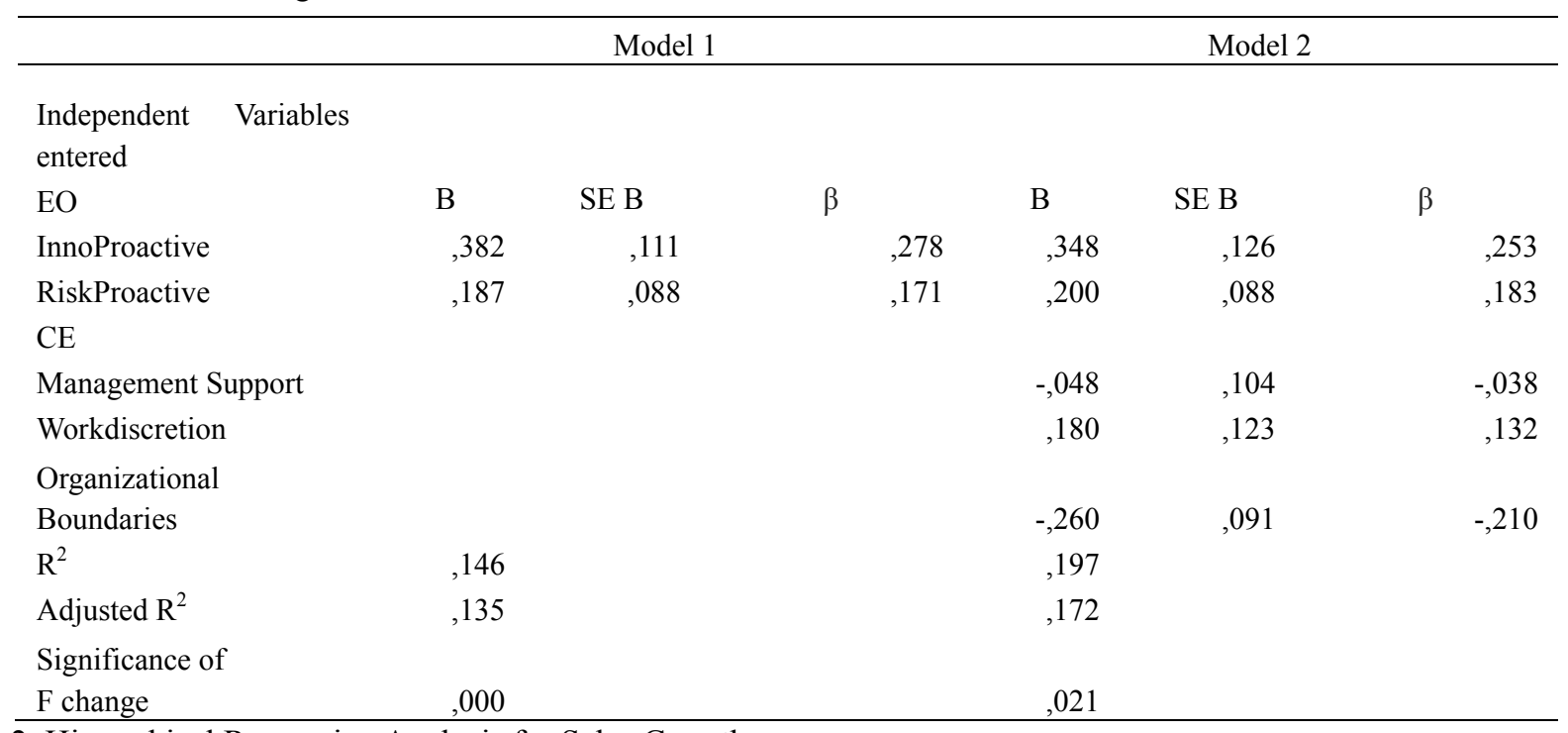

5.3.2. Hierarchical Regression Analysis for Sales Growth

As we mentioned above the relationship between entrepreneurial orientation and exportation is not supported by our data until we include the mediator effect of corporate entrepreneurship. The regression explain that Organizational boundaries inversely $(p=0,005<0,05)$ and proactive risk taking directly $(p=0,034<0,05)$ affect exportation of performance. However, management support $(\mathrm{p}=0,376>0,05)$, work discretion $(\mathrm{p}=0,562>0,05)$ and proactive 
innovativeness $(\mathrm{p}=0,226>0,05)$ does not influence exportation

Table 4. Hierarchical Regression Analysis for Exportation

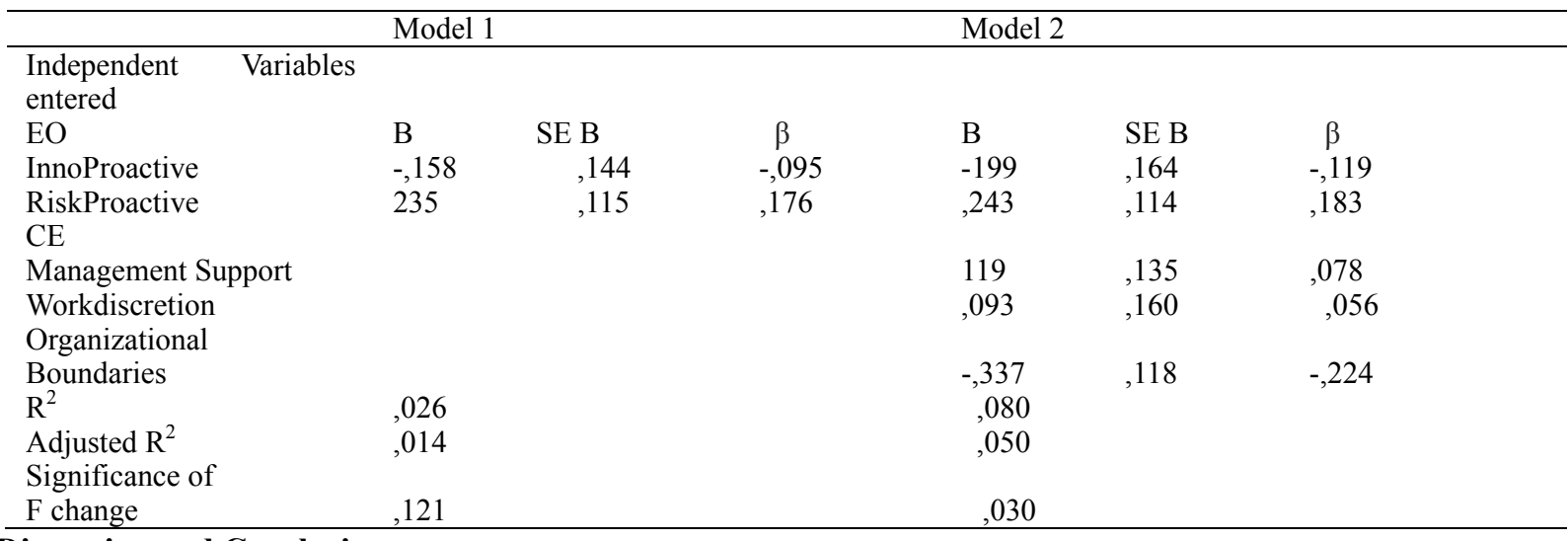

6. Discussion and Conclusion

According to regression analysis, there is a significant relationship between entrepreneurial orientation and economic performance just as Dess, Lumpkin and McGee (1999), Zahra and Covin (1995), Wiklund and Shepherd (2004) proposed. According to Lumpkin and Dess (1996) EO is at the core of growth orientation. Consistent with the results of Lee and Pennings (2001), Wiklund (1999) and Covin,Green and Slevin (2006) EO has positive effect on sales growth rate (Green et al, 2008). When we examine the relationship between dimensions, it is seen that both variables proactive innovativeness and proactive risktaking have effect on sales growth. It has seen that proactive innovativeness has a greater effect on sales growth dimension of performance than proactive risk taking. But when we analyzed the relationship between $\mathrm{EO}$ and exportation dimension of performance, it is not significant untill we included the mediator effect of CE.

Corporate entrepreneurship relationship with performance is also demonstrated by Covin and Miles in 1999, Hornsby, Kuratko and Montagno in 1999. Zahra $(1991,1993,1996)$ also has given attention to financial payoff from CE. In our regression analyses it has been found that the relationship between work discretion sales growth is significant. Work discretion consistent with Burgelman's (1983) observations about lower-level employees' corporate support to have their innovative ideas recognized. However through our regression analyses organizational boundaries inversely related with the sales growth dimesion of performance. Accordingly as OB decrease sales growth increase. Besides we also have found the relationship between organizational boundaries dimension of corporate entrepreneurship and exportation dimension of performance which are inversely correlated just as the sales growth. Thusly still as OB diminish , exportation augment.

The widespread use of the Covin and Slevin scales, coupled with researchers' emphasis on EO, might have led some to believe that the two research streams (CE and EO) were one and the same (Zahra et al, 2013). Thusly when we applied Hierarchical Regression Analysis in order to find the effect of $\mathrm{CE}$ and $\mathrm{EO}$ together on sales growth dimension of performance, it has found out organizational boundaries dimension of CE still inversely and the two both dimension of EO, proactive risktaking and proactive innovativeness influence the sales growth. The relationship between EO and exportation measure of performance is not significant. But when we included the mediator effect of $\mathrm{CE}$, the relationship between $\mathrm{EO}$ and $\mathrm{CE}$ together with the exportation dimension of performance has become significant. Consequently it has seen that organizational boundaries dimension of $\mathrm{CE}$ is inversely related as general with proactive risktaking dimension of EO to exportation.

In sum, the results of this study showed flexible organizational boundaires is useful to promote entrepreneurial activities due to they enhance the flow of information between departments or divisions and taking initiative within the organization. Another crucial finding is the role of proactiveness which has also shown its main impact on sales growth and exportation in hypothesis testings. Thusly the SMEs need to challenge in the competition and revise rules of rivalry in their industries. As Miller suggested in 1983 proactive firms pursue the promising opportunities rather than responding to competitor's moves. Hence proactive firms such as pioneering or first entrant can improve company performance (Zahra and Garvis, 2000).

\section{References}

Alarape, A. A. (2014). Developing the Entrepreneurial Orientation of OwnerManagers of Small and Medium Enterprises in Nigeria, Ife Center for Psychological Studies Nigeria, 22(1), 218-231. http://hdl.handle.net/10520/EJC150774 
Anderson, B. S., \& Eshima, Y. (2013). The influence of firm age and intangible resource on the relationship between entrepreneurial orientation and firm growth among Japanese SMEs, Journal of Business Venturing, 28, 413-429, https://doi.org/10.1016/j.jbusvent.2011.10.001

Antoncic, B., \& Hisrich, R. D. ( 2001). Intrapreneurship: Construct Refinement and Cross-Cultural Validation, Journal of Business Venturing, 16, 495-527, https://doi.org/10.1016/S0883-9026(99)00054-3

Audretsch, D. (2012). Entrepreneurship research, Management Decision, 50(5), 755-764, http://dx.doi.org/10.1108/00251741211227384

Brenkert, G. G. (2009). Innovation, rule breaking and the ethics of entrepreneurship, Journal of Business Venturing, 24, 448-464. https://doi.org/10.1016/j.jbusvent.2008.04.004

Bucktowar, R., Kocak, A., \& Padachi, K. (2015). Entrepreneurial Orientation, Market Orientation and Networking: Impact on Innovation and Firm Performance, Journal of Development Entrepreneurship, 20(4). https://doi.org/10.1142/S1084946715500247

Covin, J. G., \& Miles, M. P. (1999). Corporate Entrepreneurship and the pursuit of competitive advantage, Entrepreneurship Theory and Practice, 47-63.

Covin, J. G., \& Wales, W. J. (2011). The Measurement of Entrepreneurial Orientation, Entrepreneurship Theory and Practice, 677- 702. http://doi.org/10.1111/j.1540-6520.2010.00432.x

Dess, G. G., \& Lumpkin, G. T. (2005). The Role Entrepreneurial Orientation in Stimulating Effective Corporate Entrepreneurship', Academy of Management Executive, 19(1), 147-156. http://doi.org/10.5465/ame.2005.15841975

Duobiene, J. ( 2017). Corporate Entrepreneurship in Lithuanian Mature Organizations:is it Really Working?, Inzinerine Ekonomika- Engineering Economics, 28(1), 56-67. https://doi.org/10.5755/j01.ee.28.1.10297

Duobiene, J. ( 2013). Corporate Entrepreneurship in Organizational Life-Cycle, Economics and Management, 18(3), 584-595. https://doi.org/10.5755/j01.em.18.3.5027

Dyduch, W. (2008). Corporate Entrepreneurship Measurement for Improving Organizational Performance, Journal of Economics \& Management, 4, 16-40.

Fayolle, A., Basso, O., \& Legrain, T. (2008). Corporate Culture and Values: Genesis and Sources of L'oreal's Entreprenerial Orientation, Journal of Small Business and Entrepreneurship, 21(2), 215-230. https://doi.org/10.1080/08276331.2008.10593423

Green, K. M., Covin, J. G., \& Slevin, D. P. (2008). Exploring the relationship between strategic reactiveness and entrepreneurial orientation: The role of structure- style fit, Journal of Business Venturing, 23, 356-383. https://doi.org/10.1016/j.jbusvent.2007.01.002

Hammer, M., \& Champly, J. (1994). Avoiding the hottest new management cure, Mansueto Ventures LLC on behalf of Inc., 16(4), 25-26.

Harms, R. (2013). Entrepreneurial Orientation to Performance: inside the black box of corporate entrepreneurship', Management, 16(4), 357-432. https://doi.org/10.3917/mana.164.0410

Hayton, J. C. (2005). Promoting corporate entrepreneurship through human resource management practices: a review of empirical research', Human Resource Management Review, 15, 21-41. https://doi.org/10.1016/j.hrmr.2005.01.003

Holmes, M., Zahra, J., Hoskisson, R., DeGhetto, K., \& Sutton, T. (2016). Two-Way Streets: The Role Institutions and Technology in Firms' Corporate Entrepreneurship and Political Strategies, Academy of Management Perspectives, 30(3), 247-272. https://doi.org/10.5465/amp.2015.0136

Hornsby, J. S., Kuratko, D. F., Holt, D. T., \& Wales, W. J. (2013). Assessing a Measurement of Organizational Preparedness for Corporate Entrepreneurship, Product Development \& Management Association, 30(5), 937-955. https://doi.org/10.1111/jpim.12038

Hulbert, B., Gilmore, A., \& Carson, D. (2013). Sources of opportunities used by growth minded owner managers of small and medium sized enterprises, International Business Review, 22, 293-303, https://doi.org/10.1016/j.ibusrev.2012.04.004

Jones, G. R., Butler, J. E. (1992). Managing internal corporate entrepreneurship: an agency theory perspective, Journal of Management, 18(4), 733-749. https://doi.org/10.1177/014920639201800408

Kaya, S., \& Alpkan, L. (2012). Problems and Solution Proposals for SMEs in Turkey, Emerging Markets Journal, 2 , 31-45. https://doi.org/10.5195/EMAJ.2012.26 
Keh, H. T., Nguyen, T. M., \& Ping, H. (2007). The effects of Entrepreneurial Orientation and Marketing Information on the performance of SMEs, Journal of Business Venturing, 22, 592-611. https://doi.org/10.1016/j.jbusvent.2006.05.003

Kreiser, P. M., \& Davis, J. (2010). Entrepreneurial Orientation and Firm Performance: The Unique Impact of Innovativeness, Proactiveness and Risk-taking, Journal of Small Business and Entrepreneurship, 23(1), 39-51. https://doi.org/10.1080/08276331.2010.10593472

Kuratko, D. F, Hornsby, J. S., \& Covin, J. G. (2014). Diagnosing a firm's internal environment for corporate entrepreneurship, Business Horizons, 57, 37-47. https://doi.org/10.1016/j.bushor.2013.08.009

Lerner, M., Azulay, I., \& Tishler, A. (2009). The Role of Compensation Methods in Corporate Entrepreneurship, International Studies of Management \& Organization, 39(3), 53-81. https://doi.org/10.2753/IMO0020-8825390303

Lumpkin, G. T., \& Dess ,G. G. (2001). Linking two Dimensions of Entpreneurial Orientation to Firm Performance: The Moderating Role of Environment and Industry Life Cycle , Journal of Business Venturing, 16, 429-451. https://doi.org/10.1016/S0883-9026(00)00048-3

Lumpkin, G. T., \& Dess, G.G. (1996). Clarifying the Entrepreneurial Orientation construct and linking it to performance, Academy of Management Review, 21(1), 135-172.

Miller, D. (1983). The correlates of entrepreneurship in three types of firms, Management Science, 29, 770-791. https://doi.org/10.1287/mnsc.29.7.770

Miller, D., \& Friesen, P. H. (1982). Innovation in conservative and entrepreneurial firms: two models of strategic momentum, Strategic Management Journal, 3, 1-25. https://doi.org/10.1002/smj.4250030102

Morrish, S. C., Miles, M. P., \& Polonsky, M. J. (2011). An Explotary Study of Sustainability as a Stimulus for Corporate Entrepreneurship, Corporate Social Responsibility and Environmental Management, 18, 162-171. https://doi.org/10.1002/csr.271

OECD (2004). Small and Medium Sized Entreprises in Turkey: Issues and Policies, Organization for Economic Co-Operation and Development, https://www.oecd.org/cfe/smes/31932173.pdf

Ozdemirci, A. (2011). Corporate Entrepreneurship and Strategy Process: A Performance Based Research on Istanbul Market, Procedia Social and Behavioral Sciences, 24, 611-626. https://doi.org/10.1016/j.sbspro.2011.09.068

Parker, S. C. (2011). Intrapreneurship or entrepreneurship?, Journal of Business Venturing, 26, 19-34. https://doi.org/10.1016/j.jbusvent.2009.07.003

Parsian, M., \& Mobaraki, M. H. (2016). Investigating the effect of entrepreneurial orientation on the formation of entrepreneurial identity, Management Sicence Letters, 6, 627-634. https:// doi.org/ 10.5267/j.msl.2016.8.006

Peltola, S. (2013). The emergence of entrepreneurship in organizations: joint decision-making about new sales practices in management group meeting interaction, Poznan University of Economics Review, 13(1), 48-67.

Schmelter, R., Mauer, R., Borsch, C., \& Brettel, M. (2010). Boosting Corporate Entrepreneurship through HRM Practices: Evidence from German SMEs, Human Resource Management, 49(4), 715- 741. Published online in Wiley InterScience. http://doi.org/10.1002/hrm.20366

Serai, M. H., Johl, S. K., \& Marimuthu, M. (2017). Overview on Relationship between Corporate Entrepreneurship and Firm Performance, Global Business Management Research: An International Journal, 9, 428-438.

Sharma, P., \& Charisman, J. J. (1999). Toward a Reconciliation of the Definitional Issues in the Fiels of Corporate Entrepreneurship, Entrepreneruship Theory and Practice, 23(3), 11-27.

Sonninen, J., Martikainen, M., Puumalainen, K., \& Kylaheiko, K. (2012). Entrepreneurial orientation: Growth and profitability of Finnish small- and medium-sized enterprises, International Journal of Production Economics, 140, 614- 621. https://doi.org/10.1016/j.ijpe.2011.05.029

TUIK (2015). Small and Medium Sized Entreprise Statistics 2015, Turkish Statistical Institute, http://www.tuik.gov.tr/PreHaberBultenleri.do?id=21864

Van Wyk, R., \& Adonisi, M. (2012). Antecedent of Corporate Entrepreneurship, South African Journal of Business Management, 43(3).

Wiklund, J., \& Shepherd, D. (2005). Entrepreneurial Orientation and small business performance: a configurational approach, Journal of Business Venturing, 20,71-91. https://doi.org/10.1016/j.jbusvent.2004.01.001

Zahra, S. A. (1991). Predictors and Financial Outcomes of Corporate Entrepreneurship: An Explatory Study, Journal of 
Business Venturing, 6(4), 259. https://doi.org/10.1016/0883-9026(91)90019-A

Zahra, S. A., \& Covin, J. G. (1995). Contextual Influences on the Corporate Entrepreneurship- Performance Relationship: A Longitudinal Analysis, Journal Business Venturing, 10(1), 43-58. https://doi.org/10.1016/0883-9026(94)00004-E

Zahra, S. A., \& Garvis, D. M. (2000). International Corporate Entrepreneurship and Firm Performance: The moderating role of International Environmental hostility, Journal of Business Venturing, 15, 469-492. https://doi.org/10.1016/S0883-9026(99)00036-1

Zahra, S. A., Nielsen, A. P., \& Bogner, W. C. (1999). Corporate Entrepreneurship Knowledge and Competence Development, Entrepreneurship Theory and Practice, 169-189.

Zahra, S. A., Randerson, K., \& Fayolle, A. ( 2013). The Evolution and Contributions of Corporate Entrepreneurship Research, Management, 16(4), 357-432. https://doi.org/10.3917/mana.164.0362

Zhang, X., Ma X., \& Wang, Y. (2012). Entrepreneurial Orientation, Social Capital and Internalization of SMEs: Evidence from China, Published online in Wiley Online Library, 195- 210. http.//doi.org/10.1002/tie.21451

\section{Copyrights}

Copyright for this article is retained by the author(s), with first publication rights granted to the journal.

This is an open-access article distributed under the terms and conditions of the Creative Commons Attribution license which permits unrestricted use, distribution, and reproduction in any medium, provided the original work is properly cited. 